Buana Sains Vol 17 No 2: 153 - 166, 2017

\title{
DAMPAK APLIKASI MULSA DAN GENERASI UMBI BIBIT (G2, G3, LOKAL) PADA TANAMAN KENTANG (Solanum tuberosum LINN)
}

\author{
Ester Ruchama Jella $1^{1} *$, Agus Suryanto $2^{2}$, Lilik Setyobudi $3^{2}$ \\ ${ }^{1}$ Politeknik Pertanian Negeri Kupang \\ ${ }^{23}$ Jurusan Budidaya Pertanian, Fakultas Pertanian, Universitas Brawijaya
}

\begin{abstract}
Sub-optimal environment condition and the use of low-quality seed tubers is a constraint to increase the yield of potato tubers. The purpose of this study was to determine the impact of the various applications of mulch and seed tuber G2, G3, local on growth and yield of potato tubers, as well as to temperature and soil moisture. The research was conducted in June-December, 2013 in the highlands $(2232.66 \mathrm{~m}$ asl) in Village Ranupani, District Senduro, Lumajang, East Java Province.

A randomized block design was used with a combination of treatments: without mulch (tm), black plastic mulch silver (mphp), blue plastic mulch (mpb), Chromolaena odorata mulch (mCo) and the mother bulb G2, G3, local. There are 12 combinations of treatment was repeated 3 times. The combination of these treatments consist of: $\mathrm{tm}+\mathrm{G} 2, \mathrm{mphp}+\mathrm{G} 2, \mathrm{mpb}+\mathrm{G} 2, \mathrm{mCo}+\mathrm{G} 2, \mathrm{tm}+\mathrm{G} 3, \mathrm{mphp}+\mathrm{G} 3, \mathrm{mpb}+\mathrm{G} 3$, $\mathrm{mCo}+\mathrm{G} 3, \mathrm{tm}+$ local, mphp+local, mpb+local, mCo+local. Data were analyzed using the $\mathrm{F}$ test with a level of $5 \%$. If a significantly different among treatment followed by LSD test $5 \%$.

The results showed the use mphp on local seed tubers are able to provide growth and potato tubers yield optimum is $641.76 \mathrm{~g} \mathrm{plant}^{-1}\left(21.39 \mathrm{t} \mathrm{ha}^{-1}\right)$ compared to other treatments, but the tuber yield did not differ significantly with the use mpb in seed tubers G2.
\end{abstract}

Keywords: mulch,the mother bulb, potato

\section{Pendahuluan}

Kentang (Solanum tuberosum L.) merupakan salah satu jenis tanaman hortikultura yang ber-nilai ekonomis tinggi. Sebagai sumber karbohidrat, umbi kentang merupakan sumber bahan pangan yang dapat menjadi alternatif bahan pa-ngan karbohidrat selain beras, jagung dan gandum (Rukmana, 2002). Mengacu pada program pemerintah akan diversifikasi sumber pangan karbohidrat non beras akhir-akhir ini, umbi kentang merupakan salah satu alternatif penting untuk keragaman bahan pangan non beras.

Dalam lima tahun terakhir, luas areal, hasil produksi, dan produktivitas kentang di Indonesia mengalami fluktuasi. Data BPS tahun 2013, menunjukan rerata produktivitas kentang di Indonesia sebesar 16,02 ton $\mathrm{ha}^{-1}$ dari rerata luas panen 70.187 ha dan rerata produksi 1.124.282 ton (BPS, 2013). Kemudian tahun 2014 produksi kentang Indonesia naik menjadi 1.316.016 ton (BPS, 2014).

Di wilayah Asia, produktivitas kentang di Indonesia masih tergolong 
rendah. Meski Indonesia memiliki zona iklim yang hampir sama dengan India dan Philippines, namun survey menunjukan produktivitas kentang di Indonesia masih berada di bawah produktivitas kentang kedua negara tersebut.

Produktivitas kentang yang relatif rendah disebabkan bibit yang digunakan mempunyai kualitas rendah, pengetahuan yang kurang tentang kultur teknis, penanaman secara terus menerus dan permodalan petani yang terbatas (Sunaryono, 2007). Lebih lanjut Rukmana 2002, menyatakan Produksi kentang nasional masih rendah karena masih menghadapi beberapa masalah meliputi: hambatan varietas, mutu bibit, teknik budidaya, serta perbaikan teknologi pra-panen dan pascapanen. Pada budidaya kentang, kontinyuitas produksi sangat tergantung pada kualitas bibit. Penggunaan bibit secara turun temurun melebihi empat generasi dapat meng-akibatkan penurunan produksi. Penggunaan bibit bermutu akan bisa meningkatkan produksi kentang. Bibit kentang bermutu dijamin melalui bibit kentang yang bersertifikat (Wattimena, 2000).

Pertumbuhan dan perkembangan tanaman dipengaruhi oleh faktor genetik dan lingkungan. Secara sederhana dirumuskan bahwa karakter tanaman yang teramati merupakan hasil kerjasama antara pengaruh genetik yang bersifat turun-temurun dan pengaruh lingkungan yang bersifat tidak menurun (Bing Tang et al., 1996). Pada kenyataannya, lingkungan tumbuh tidak selalu merupakan lingkungan optimum bagi pertumbuhannya sehingga seringkali tanaman tidak mampu mengekspresikan seluruh potensi genetik yang dimilikinya.

Salah satu tujuan manipulasi lingkungan melalui kultur teknik adalah untuk memperoleh kondisi lingkungan tumbuh yang sesuai untuk tanam-an, misalnya dengan pemberian mulsa dan meng-gunakan benih bermutu. Rukmana, 2002, mengatakan penggunaan mulsa plastik pada tanaman kentang dapat mengurangi serangan penyakit layu bakteri, selain itu dapat juga meningkatkan produksi. Mulsa plastik yang di-gunakan dapat mengatur suhu tanah, meng-hambat perkembangan hama dan penyakit, me-ngurangi kelembaban udara di sekitar tanaman, menekan pertumbuhan gulma, memantulkan cahaya, melindungi pupuk dari pencucian dan meningkatkan efisiensi penggunaan pupuk nitrogen.

El-Zohiri dan M. Samy (2013) melaporkan, mulsa plastik hitam menghasilkan suhu tanah yang lebih tinggi sedangkan mulsa merah menunjukkan kelembaban tertinggi $(23.45 \%)$, diikuti oleh mulsa plastik hitam $(22.75 \%)$ dan mulsa plastik biru (20,88\%). Mulsa hitam secara signifikan meningkatkan tingkat perkecambahan dan jumlah batang per tanaman, sedangkan mulsa merah memperlihatkan nilai tertinggi dalam semua sifat pertumbuhan, hasil panen dan kualitas.

Wang et al. (1998) dan Ashrafuzzaman et al. (2011) melaporkan bahwa semua jenis mulsa plastik meningkatkan kadar air tanah dibandingkan dengan kontrol. Zaoet al. (2012)dalam penelitiannya melaporkan bahwa mulsa plastik menghangatkan tanah lapisan atas dan meningkatkan kadar air tanah lapisan atas. Suhu tanah harian lapisan atas rata-rata dalam plot bermulsa adalah $2,5-3,2^{\circ} \mathrm{C}$ lebih tinggi dari pada kontrol selama awal pertumbuhan. Masud et al. (2002) dalam laporannya menunjukkan bahwa, umbi bibit kentang yang ditanam di bawah mulsa plastik hitam membutuhkan waktu terpendek dalam pertumbuhannya yaitu selama 13.92 hari untuk mencapai 
$80 \%$ munculnya tunas. Pertumbuhan vegetatif dan hasil juga dipengaruhi oleh penggunaan mulsa plastik. Hasil penelitian Luiss at al. (2011) menunjukkan bahwa tanaman yang tumbuh di bawah mulsa plastik hitam, yang disebabkan suhu tanah tertinggi, me-nunjukkan perbedaan dalam hasil dibandingkan dengan tanaman kontrol, bahwa mulsa plastik berwarna memiliki efek positif pada hasil melalui penurunan suhu tanah. Lebih lanjut, hasil penelitian Tinambunan at al. (2014) melaporkan perlakuan mulsa plastik hitam, mulsa plastik hitam perak, dan mulsa plastik transparan menghasilkan panjang, diameter, bobot umbi per tanaman, bobot segar umbi panen pada luasan $1 \mathrm{~m}^{2}$, bobot segar total tanaman, dan laju pertumbuhan tanaman wortel yang lebih baik dari pada perlakuan tanpa mulsa.

Efek aplikasi mulsa ditentukan oleh jenis ba-han mulsa. Bahan yang dapat digunakan sebagai mulsa di antaranya sisa-sisa tanaman (serasah dan jerami) atau bahan plastik. Menurut Mahmood et al. (2002), mulsa jerami atau mulsa yang berasal dari sisa tanaman lainnya mempunyai konduktivitas panas rendah sehingga panas yang sampai ke permukaan tanah akan lebih sedikit dibandingkan dengan tanpa mulsa atau mulsa dengan konduktivitas panas yang tinggi seperti plastik. Jadi jenis mulsa yang berbeda memberikan pengaruh berbeda pula pada pengaturan suhu, kelembaban, kandungan air tanah, penekanan gulma dan organisme pengganggu. Namun usaha dalam manipulasi lingkungan tumbuh dengan teknik budidaya tersebut akankah berbeda pengaruhnya jika dilakukan pada tanaman kentang dengan umbi bibit yang berbeda generasi, begitu juga perbedaan jenis mulsa akankah berbeda pengaruhnya terhadap perbedaan suhu dan ke-lembaban tanah, sehingga pertumbuhan dan hasil umbi kentang untuk tiap generasi umbi bibit akan berbeda pula.

Penelitian ini bertujuan untuk mengetahui dampak aplikasi mulsa plastik hitam perak (mphp), mulsa plastik biru (mpb), mulsa Chromo-laena odorata $(\mathrm{mCo})$ dan tanpa mulsa (tm) de-ngan generasi umbi bibit G2, G3, lokal, terhadap pertumbuhan dan hasil umbi kentang, serta dampaknya terhadap suhu dan kelembaban tanah. Penelitian ini diharapkan dapat menemukan kombinasi jenis mulsa dan generasi umbi bibit yang tepat, sehingga mampu meningkatkan produksi umbi kentang.

\section{METODE PENELITIAN}

Percobaan lapang disusun dalam Rancangan Acak Kelompok dengan kombinasi perlakuan: tanpa mulsa (tm), mulsa plastik hitam perak (mphp), mulsa plastik biru (mpb), mulsa Chromo-laena odorata $(\mathrm{mCo})$ dan umbi bibit G2, G3, lokal.Terdapat 12 kombinasi perlakuan yang diulang 3 kali.Jadi total satuan percobaan adalah 36 plot. Kombinasi perlakuan tersebut terdiri dari: $\mathrm{tm}+\mathrm{G} 2$ (A), mphp+G2 (B), mpb+G2 (C), $\mathrm{mCo}+\mathrm{G} 2$ (D), tm+G3 (E), mphp+G3 (F), mpb+G3 (G), $\quad \mathrm{mCo}+\mathrm{G} 3 \quad(\mathrm{H})$, tm+lokal (I), mphp+lokal (J), mpb+lokal (K), mCo+lokal (L).

Data hasil pengamatan dianalisis dengan analisis ragam (uji F) mengikuti model RAK. Apabila hasil analisis terdapat pengaruh yang signifikan maka untuk melihat perbedaan antar perlakuan dilanjutkan dengan uji Beda Nyata Terkecil (BNT) pada taraf 5\%.

\section{Metode Pengumpulan Data}

Parameter yang diamati adalah komponen pertumbuhan, komponen hasil, dan komponen lingkungan mikro. Pengamatan yang diamati secara non 
destruktif adalah jumlah cabang. Sedangkan yang diamati secara destruktif adalah luas daun, bobot kering total tanaman dan hasil panen. Pengamatan komponen pertumbuhan di-lakukan mulai umurtanaman 30 hst dengan interval 15 hari. Dari data tersebut dihitung LPT, LAB, ILD, berat segar umbi panen total petak ${ }^{-1}$ dan hektar ${ }^{-1}$. Pengamatan setelah panen adalah berat segar umbi panen total tanaman ${ }^{-1}$ dan klas-ifikasinya, jumlah umbi totaltanaman ${ }^{-1}$ dan klasifikasinya.

Selain itu dilakukan juga pengamatan komponen lingkungan mikro yaitusuhu dan kelembaban tanah.Pengamatan pendukung yaitu suhu udara, koordinat lokasi dan elevasi, $\mathrm{pH}$ tanah.

\section{HASIL DAN PEMBAHASAN}

\section{Luas Daun}

Luas daun tanaman ${ }^{-1}$ menunjukkan pengaruh yang sangat nyata pada umur 45-90 hst antar perlakuan kombinasi mulsa dan generasi umbi bibit. Pada tabel 1 memperlihatkan, perkembangan luas daun pada semua perlakuan meningkat sam-pai kisaran umur 60-75 hst, kemudian berangsur me-nurun sejalan dengan senescen tanaman. Pada saat luas daun mencapai maksimal yakni pada 60 hst penggunaan mphp pada umbi bibit G3 dan lokal memberikan luas daun tertinggi. Demikian pula penggunaan mphp dan mpb pada umbi bibit G2. Untuk penggunaan umbi bibit G3 dan G2 dengan mphp dan mpb, luas daun berkurang hing-ga akhir pengamatan, namun pada penggunaan umbi bibit lokal sejak 75 hst luas daun menurun secara drastis. Pada Gambar 1 terlihat penggunaan mphp pada umbi bibit G3 memberikan luas daun tertinggi (optimum) pada umur 60 hst. Hal ini dipahami bahwa penggunaan mphp berdampak pada kadar air tanah yang cukup memadai di rbizosfer. Ini ditunjukan dengan rerata kelembaban tanah ter-tinggi yakni $83,47 \%$ pada pagi hari. Kelembaban tanah yang cukup akan berpengaruh pada pe-nyerapan unsur hara yang optimum sehingga berdampak pada peningkatan luas daun dan ILD. Selain itu permukaan warna perak pada mphp berdampak pada intersepsi sinar matahari yang lebih optimal sehingga meningkatkan pertumbuhan daun. Meningkatnya luas daun juga meningkatkan nilai ILD. Nilai ILD yang optimum ber-pengaruh pada akumulasi assimilat yang dihasilkan, yang nantinya akan berdampak pada peningkatan bobot kering tanaman dan hasil umbi.

\section{Indeks Luas Daun (ILD)}

Hasil analisis ragam terhadap rerata ILD memperlihatkan pengaruh nyata pada umur tanaman 30 hst dan sangat nyata pada umur tanaman 45-105 hst antar perlakuan kombinasi mulsa dan generasi umbi bibit. Data ILD pada Tabel 2.memperlihatkan, perkembangan ILD pa-da semua perlakuan meningkat sampai kisaran umur 60-75 hst, kemudian berangsur menurun sejalan dengan senescen tanaman. Pada saat ILD mencapai maksimal yakni pada 60 hst penggunaan mphp pada umbi bibit G3 dan lokal memberikan ILD tertinggi. Demikian pula penggunaan mphp dan mpb pada umbi bibit G2. Untuk penggunaan umbi bibit G3 dan G2 dengan mphp dan mpb, ILD berkurang hingga akhir pengamatan yaitu umur 90 hst, namun pada penggunaan umbi bibit lokal sejak 75 hst ILD menurun secara drastis. 
E.R.Jella, A. Suryanto,dan L. Styobudi/Buana Sains Vol 17 No 2 : 153-166

Tabel 1. Rerata Luas Daun $\left(\mathrm{cm}^{2} \tan ^{-1}\right)$ Sebagai Dampak Aplikasi Mulsa dan Generasi Umbi Bibit G2, G3,Lokal) Umur 30-90 hst

\begin{tabular}{|c|c|c|c|c|c|}
\hline \multirow{2}{*}{$\begin{array}{c}\text { Umur } \\
\text { Tanaman }\end{array}$} & \multirow{2}{*}{$\begin{array}{c}\text { Generasi } \\
\text { Umbi }\end{array}$} & \multicolumn{4}{|c|}{ Macam Mulsa } \\
\hline & & $\mathrm{tm}$ & $\mathrm{mphp}$ & $\mathrm{mpb}$ & $\mathrm{mCo}$ \\
\hline \multirow{4}{*}{30 hst } & G2 & $254,91 \mathrm{ab}$ & $297,63 \mathrm{ab}$ & 188,81 a & 178,76 a \\
\hline & G3 & 188,59 a & $615,71 \mathrm{bcd}$ & 404,76 abc & $249,94 \mathrm{ab}$ \\
\hline & Lokal & $402,05 \mathrm{abc}$ & $741,20 \mathrm{~cd}$ & $976,05 \mathrm{~d}$ & $557,94 \mathrm{abc}$ \\
\hline & BNT5\% & \multicolumn{4}{|c|}{417,66} \\
\hline \multirow{4}{*}{45 hst } & G2 & 532,46 a & $1072,57 \mathrm{ab}$ & 1258,10 abc & 711,37 a \\
\hline & G3 & $931,24 \mathrm{ab}$ & $1263,41 \mathrm{abc}$ & $2188,13 \mathrm{~cd}$ & $927,78 \mathrm{ab}$ \\
\hline & Lokal & $1440,02 \mathrm{abc}$ & $1378,24 \mathrm{abc}$ & $3073,95 \mathrm{~d}$ & $1931,63 \mathrm{bc}$ \\
\hline & BNT5\% & \multicolumn{4}{|c|}{1107,00} \\
\hline \multirow{4}{*}{60 hst } & G2 & $701,72 \mathrm{a}$ & 2971,37 a & $2367,14 \mathrm{bcd}$ & $939,77 \mathrm{abcd}$ \\
\hline & G3 & 1019,03 a & $5422,21 \mathrm{e}$ & 2140,27 abc & $1392,88 \mathrm{ab}$ \\
\hline & Lokal & $1515,18 \mathrm{ab}$ & 4077,10 de & 3861,32 cde & $2106,78 \mathrm{ab}$ \\
\hline & BNT5\% & \multicolumn{4}{|c|}{1751,42} \\
\hline \multirow{4}{*}{75 hst } & G2 & 480,96 a & $4057,88 \mathrm{~cd}$ & $1290,15 \mathrm{ab}$ & $1613,00 \mathrm{ab}$ \\
\hline & G3 & $1192,27 \mathrm{ab}$ & $3511,57 \mathrm{c}$ & $5118,85 \mathrm{~d}$ & $1057,16 \mathrm{ab}$ \\
\hline & Lokal & $734,85 \mathrm{ab}$ & $1842,95 \mathrm{ab}$ & $2088,46 \mathrm{~b}$ & $1149,66 \mathrm{ab}$ \\
\hline & BNT5\% & \multicolumn{4}{|c|}{1384,11} \\
\hline \multirow{3}{*}{90 hst } & G2 & 313,20 a & 1207,09 bc & $1422,55 \mathrm{~cd}$ & $1070,45 \mathrm{abc}$ \\
\hline & G3 & $507,87 \mathrm{ab}$ & $2175,07 \mathrm{~d}$ & $2137,96 \mathrm{~d}$ & $480,11 \mathrm{ab}$ \\
\hline & Lokal & $615,72 \mathrm{ab}$ & $1489,84 \mathrm{~cd}$ & $1043,80 \mathrm{abc}$ & $422,40 \mathrm{a}$ \\
\hline
\end{tabular}

Keterangan: Bilangan yang didampingi oleh huruf yang sama pada umurtanaman yang sama, berbeda tidak nyata berdasarkan ujiBNTpada taraf 5\%. hst=hari setelah tanam. $\mathrm{mphp}=$ mulsa plastik hitamperak, $\mathrm{mpb}=$ mulsa plastik

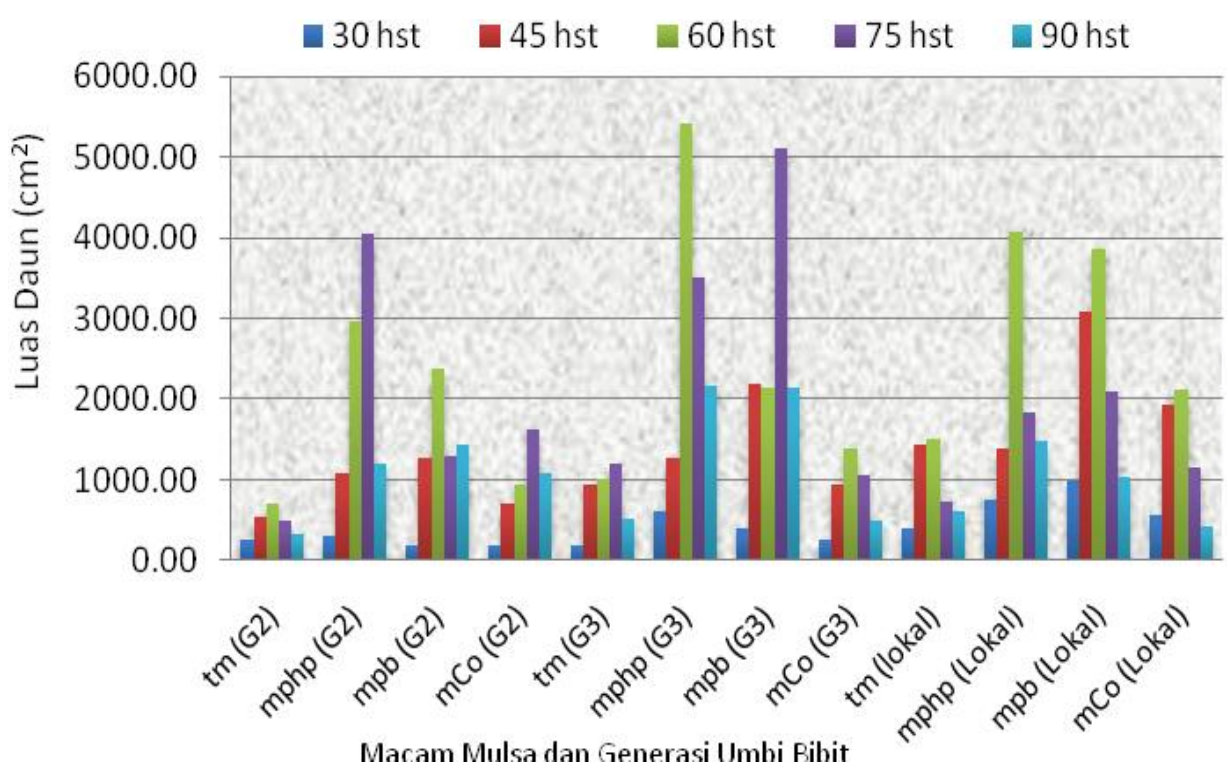

Gambar 1. Luas Daun pada Umur 30-90 hst 
Tabel 2. Rerata ILD Sebagai Dampak Aplikasi Mulsa dan Generasi Umbi Bibit G2, G3, Lokal) Umur 30-105 hst

\begin{tabular}{|c|c|c|c|c|c|}
\hline \multirow{2}{*}{$\begin{array}{c}\text { Umur } \\
\text { Tanaman }\end{array}$} & \multirow{2}{*}{$\begin{array}{c}\text { Generasi } \\
\text { Umbi }\end{array}$} & \multicolumn{4}{|c|}{ Macam Mulsa } \\
\hline & & $\mathrm{tm}$ & mphp & $\mathrm{mpb}$ & $\mathrm{mCo}$ \\
\hline \multirow{3}{*}{30 hst } & G2 & $0,12 \mathrm{ab}$ & $0,14 \mathrm{ab}$ & $0,09 \mathrm{a}$ & $0,09 \mathrm{ab}$ \\
\hline & G3 & $0,09 \mathrm{ab}$ & $0,29 \mathrm{bcd}$ & $0,19 \mathrm{abc}$ & $0,12 \mathrm{ab}$ \\
\hline & Lokal & $0,19 \mathrm{abc}$ & $0,35 \mathrm{~cd}$ & $0,46 \mathrm{~d}$ & $0,27 \mathrm{abcd}$ \\
\hline & BNT5\% & & 0,20 & & \\
\hline \multirow{3}{*}{45 hst } & G2 & $0,25 \mathrm{a}$ & $0,51 \mathrm{abc}$ & $0,60 \mathrm{abc}$ & $0,34 \mathrm{ab}$ \\
\hline & G3 & $0,44 \mathrm{ab}$ & $0,53 \mathrm{abc}$ & $1,00 \mathrm{c}$ & $0,44 \mathrm{ab}$ \\
\hline & Lokal & $0,66 \mathrm{abc}$ & $0,76 \mathrm{abc}$ & $1,62 \mathrm{~d}$ & $0,85 \mathrm{bc}$ \\
\hline & BNT5\% & & 0,51 & & \\
\hline \multirow{3}{*}{60 hst } & G2 & $0,33 \mathrm{a}$ & $1,41 \mathrm{bcd}$ & 1,13 abcd & $0,45 \mathrm{a}$ \\
\hline & G3 & $0,49 \mathrm{a}$ & $2,58 \mathrm{e}$ & $1,02 \mathrm{abc}$ & $0,66 \mathrm{ab}$ \\
\hline & Lokal & $0,72 \mathrm{ab}$ & $1,94 \mathrm{de}$ & 1,84 cde & $1,00 \mathrm{abc}$ \\
\hline & BNT5\% & & 0,83 & & \\
\hline \multirow{3}{*}{75 hst } & G2 & $0,23 \mathrm{a}$ & $1,93 \mathrm{ef}$ & 1,30 cde & $0,77 \mathrm{abc}$ \\
\hline & G3 & $0,57 \mathrm{abc}$ & $1,67 \mathrm{de}$ & $2,44 \mathrm{f}$ & $0,50 \mathrm{ab}$ \\
\hline & Lokal & $0,35 \mathrm{ab}$ & 0,88 abc & $0,99 \mathrm{bcd}$ & $0,55 \mathrm{abc}$ \\
\hline & BNT5\% & & 0,75 & & \\
\hline \multirow{4}{*}{90 hst } & G2 & $0,15 \mathrm{a}$ & $0,57 \mathrm{bc}$ & $0,68 \mathrm{~cd}$ & $0,51 \mathrm{abc}$ \\
\hline & G3 & $0,24 \mathrm{ab}$ & $1,04 \mathrm{~d}$ & $1,02 \mathrm{~d}$ & $0,23 \mathrm{ab}$ \\
\hline & Lokal & $0,29 \mathrm{ab}$ & $0,71 \mathrm{~cd}$ & $0,50 \mathrm{abc}$ & $0,20 \mathrm{ab}$ \\
\hline & BNT5\% & & 0,37 & & \\
\hline
\end{tabular}

Keterangan: Bilangan yang didampingi oleh huruf yang sama pada umur tanaman yang sama, berbeda tidak nyata berdasarkan uji BNT pada taraf $5 \%$. hst $=$ hari setelah tanam. $\mathrm{mphp}=$ mulsa plastik hitam perak, $\mathrm{mpb}=$ mulsa plastik biru, $\mathrm{mCo}=$ mulsa Chromolaena odorata

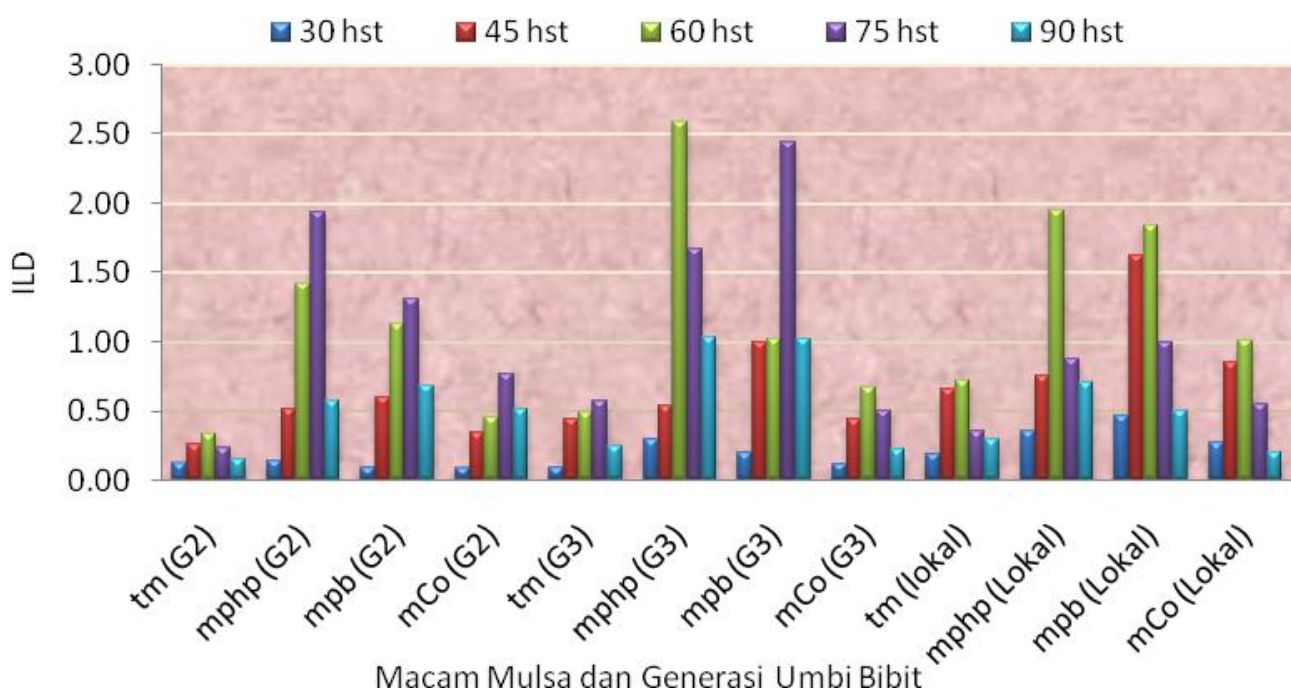

Gambar 2. ILD pada Umur 30-90 hst 
Produksi tanaman budidaya merupakan cara praktis untuk menjerat energi matahari dan mengubahnya menjadi makanan dan bahan-bahan lain yang dapat dimanfaatkan. Semakin besar nilai ILD akan berpengaruh terhadap penyerapan energi matahari yang akan berimbaspada peningkatan hasil umbi. Pada Gambar 2 tampak penggunaan mphp pada umbi bibit G3 umur 60 hst memberikan nilai ILD tertinggi dibandingkan perlakuan lainnya. Nilai ILD tertinggi yakni 2,58 yang setara dengan luas daun $5422,21 \mathrm{~cm}^{2}$ berada pada kisaran yang sesuai dengan hasil penelitian Basuki, Suryanto, Maghfoer, Koesriharti, Aini dan Rosilawati (1993), yang melaporkan produktivitas 10 varietas kentang berkisar 11-27 ton $\mathrm{ha}^{-1}$, memiliki ILD sebesar 1,26-3,93, yang se-tara dengan luas daun sebesar 2.650-8.253 $\mathrm{cm}^{2}$. Odjugo (2007) mengungkapkan bahwa perlakuan mulsa memiliki tingkat pertumbuhan yang lebih baik dari pada tanpa pemulsaan. Mulsa meningkatkan kondisi iklim mikrotanah sehingga akar berkembang dengan baik dibandingkan dengan perlakuan tanpa mulsa. Efek dari perkembangan akar yang baik berpengaruh terhadap perluasan daun yang maksimal. Hal senada dilaporkan Zao at al. (2012) yang menyatakan, pada tanaman kentang yang ditanam menggunakan mulsa plastik, signifikan meningkatkan tinggitanaman, ILDdan bahan kering tanaman dibandingkan tanpa mulsa.

\section{Bobot Kering Tanaman}

Antar perlakuan kombinasi mulsa dan generasi umbi bibit umur 60105 hst menunjukan beda nyata. Tabel 3 memperlihatkan, perkembangan bobot kering total yang terus meningkat sejak awal hingga akhir pengamatan yakni umur 105 hst. Perkembangan bobot kering total sejak 60 hst menunjukan penggunaan mpb pada umbi bibit lokal memberikan peningkatan bobot kering to-tal. Pada pengamatan selanjutnya 75 dan 90 hst penggunaan mphp dan mpb pada umbi bibit lokal, G3 dan G2 masih memberikan peningkatan bobot kering total yang sama. Namun pada pengamatan akhir yakni 105 hst, penggunaan mpb pada umbi bibit G3 memberikan bobot kering total yang ada. Penggunaan mpb pada umbi bibit G2 dan lokal mampu terus meningkatkan bobot kering total hingga akhir pengamatan yakni 105 hst. Demikian pula penggunaan mphp pada umbi bibit G2, G3, lokal, masih mampu mempertahankan bobot kering total. Gambar 3 menunjukan penggunaan mpb pada umbi bibit G3 tampaknya memberikan bobot kering total tertinggi pada 105 hst dibanding perlakuan lainnya. $\quad \mathrm{Hal}$ ini dikarenakan penggunaan mpb pada umbi bibit G3 masih mampu me-ningkatkan luas daun hingga umur 75 hst karena berada pada kelembaban tanah yang memadai yakni $>58 \%$ dibanding perlakuan lainnya. Tinggi-nya kelembaban tanah pada mpb disinyalir karena sifat fisik mpb yang transparant mampu meloloskan cahaya matahari. Ini menyebabkan benihbenih gulma mampu tumbuh di bawah tutupan mpb, akibatnya pada saat terjadi transpirasi titik-titik air tertahan oleh mulsa dan jatuh kembali ke tanah. Kondisi ini turut memberikan kontribusi terhadap kelembaban tanah di bawah tutupan mpb. Ketersediaan air tanah yang memadai memicu pertumbuhan tajuk tanaman yang terlihat dari kemampuan menambah luas daun hingga 75 hst. Ini berdampak pada peningkatan akumulasi bahan 
kering pada organ batang dan daun (brangkasan), sehingga bobot kering total tanaman juga meningkat. Namun peningkatan bobot kering total tidak diikuti dengan peningkatan hasil umbi. Disinyalir suhu tanah yang lebih tinggi pada mpb dibanding perlakuan lain yakni $>20^{\circ} \mathrm{C}$ menghambat pembesaran umbi. Menurut Li (2004) suhu tinggi, dapat meningkatkan kerja beberapa enzim yang selanjutnya dapat menekan metabolisme pati sehingga terjadi penurunan kadar pati pada umbi yang secara langsung menghambat perombakan gula menjadi pati. Hal tersebut menyebabkan kandungan pati pada tanaman kentang pada suhu tinggi menjadi berkurang pada kadar pati yang dimilikinya

Tabel 3. Rerata Bobot Kering Total $\left(g\right.$ tan. $\left.{ }^{-1}\right)$ Sebagai Dampak Aplikasi Mulsa dan Generasi Umbi Bibit (G2,G3, Lokal) Umur 60-105 hst

\begin{tabular}{|c|c|c|c|c|c|}
\hline \multirow{2}{*}{$\begin{array}{c}\text { Umur } \\
\text { Tanaman }\end{array}$} & \multirow{2}{*}{$\begin{array}{c}\text { Generasi } \\
\text { Umbi Bibit }\end{array}$} & \multicolumn{4}{|c|}{ Macam Mulsa } \\
\hline & & $\mathrm{tm}$ & mphp & $\mathrm{mpb}$ & $\mathrm{m} C_{0}$ \\
\hline \multirow{3}{*}{60 hst } & G2 & 11,05 a & $12,95 \mathrm{ab}$ & $12,99 \mathrm{ab}$ & $11,42 \mathrm{a}$ \\
\hline & G3 & $13,63 \mathrm{ab}$ & 16,98 abc & 29,89 bc & $23,86 \mathrm{abc}$ \\
\hline & Lokal & $29,93 \mathrm{bc}$ & $30,90 \quad \mathrm{bc}$ & $71,09 \quad \mathrm{~d}$ & $34,67 \quad c$ \\
\hline \multicolumn{2}{|r|}{ BNT5\% } & \multicolumn{2}{|r|}{17,95} & & \\
\hline \multirow{3}{*}{75 hst } & $\mathrm{G} 2$ & 24,07 a & 63,49 abcd & $50,47 \mathrm{abc}$ & 24,52 a \\
\hline & G3 & $30,61 \mathrm{ab}$ & $83,87 \quad \mathrm{~cd}$ & $38,13 \mathrm{ab}$ & $28,28 \mathrm{ab}$ \\
\hline & Lokal & $34,54 \mathrm{ab}$ & 95,57 & $131,07 \mathrm{e}$ & $68,20 \mathrm{bcd}$ \\
\hline \multicolumn{2}{|r|}{ BNT5\% } & & 42,13 & & \\
\hline \multirow{3}{*}{90 hst } & $\mathrm{G} 2$ & 36,17 a & $116,67 \mathrm{bc}$ & $156,27 \mathrm{~cd}$ & 50,93 a \\
\hline & G3 & 44,57 a & $145,10 \mathrm{~cd}$ & $187,60 \quad \mathrm{~d}$ & 40,87 a \\
\hline & Lokal & $70,97 \mathrm{ab}$ & $112,53 \mathrm{bc}$ & $142,47 \mathrm{~cd}$ & $76,30 \mathrm{ab}$ \\
\hline \multicolumn{2}{|r|}{ BNT5\% } & & 59,19 & & \\
\hline \multirow{3}{*}{105 hst } & $\mathrm{G} 2$ & 53,77 a & $125,83 \mathrm{bc}$ & $162,67 \mathrm{c}$ & 63,80 a \\
\hline & G3 & $75,23 \mathrm{ab}$ & $148,83 \quad c$ & $235,50 \mathrm{~d}$ & 45,70 a \\
\hline & Lokal & $81,85 \mathrm{ab}$ & $177,93 \quad \mathrm{c}$ & $159,50 \mathrm{c}$ & $78,75 \mathrm{ab}$ \\
\hline
\end{tabular}

Keterangan: Bilangan yang didampingi oleh huruf yang sama pada umur tanaman yang sama, berbeda tidak nyata. Berdasarkan uji BNT pada taraf 5\%. hst =hari setelah tanam. $\mathrm{mphp}=$ mulsa plastik hitam perak, $\mathrm{mpb}=$ mulsa plastik biru, $C_{0}=$ mulsa Chromolaena odorata

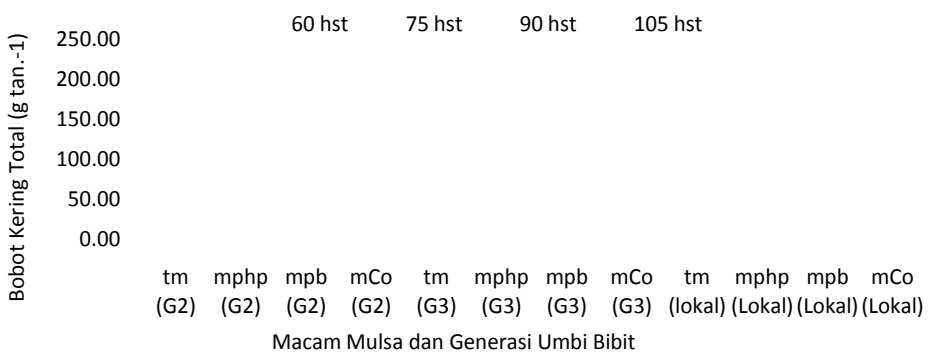

Gambar 3. Bobot Kering Total pada Umur 60-105 hst 


\section{Laju Pertumbuhan Tanaman (LPT)}

Antar perlakuan kombinasi mulsa dan generasi umbi bibit menunjukan perbedaan nyata. Tabel 4 menunjukan penggunaan mphp pada umbi bibit lokal dan mpb pada umbi bibit G3 memberikan nilai LPT yang sama, kemudian disusul oleh pengunaan $\mathrm{mpb}$ pada umbi bibit lokal, G2, dan penggunaan mphp pada umbi bibit G3.

Gambar 4 menunjukan, penggunaan mpb pada umbi bibit G3 dan mphp pada umbi bibit lokal memberikan nilai LPT yang sama dibanding perlakuan lainnya. Tingginya nilai LPT pada mpb untuk umbi bibit G3 disinyalir karena kontribusi bahan kering dari brangkasan dipengaruhi oleh luas daun yang terus meningkat hingga $75 \mathrm{hst}$. Se-mentara, penggunaan mphp pada umbi bibit lokal yang juga memberikan nilai LPT yang tinggi dibanding perlakuan lainnya, mengindikasikan bahwa penyerapan energi matahari yang ditangkap tajuk tanaman lebih efektif, karena permukaan warna perak mphp mampu memantulkan sebagian besar cahaya ke seluruh tajuk tanaman sehingga fotosintesis lebih maksimal dan selanjutnya berdampak pada peningkatan akumulasi bahan kering yang sebagian besar ditimbun pada hasil umbi.

Di sisi lain mphp mampu membuat lingkungan tumbuh lebih disukai tanaman kentang, seperti ditunjukan dengan suhu tanah pagi yang rendah yakni $13^{\circ} \mathrm{C}$. Suhu tanah yang rendah berpengaruh memberikan kelembaban tanah yang tinggi, mengurangi pemadatan tanah sehingga akar lebih mudah mengeksplorasi unsur hara dari tanah. Selain itu suhu tanah yang rendah akan berpe-ngaruh terhadap translokasi fotosintat ke bagian umbi. Mahmood et al. (2006) menyatakan, suhu tanah berhubungan dengan proses penyerapan unsur hara oleh akar, fotosintesis dan respirasi. Selain itu, Midmore (1984) menyatakan suhu tanah siang dan malam yang rendah mempercepat pertumbuhan tanaman, sedangkan suhu tanah siang dan malam tinggi memperlambat tumbuhnya tanaman di atas tanah. Disamping itu dengan penggunaan mphp pertumbuhan gulma terhambat sehingga tidak ada kompetitor dalam penyerapan unsur hara pada tanaman kentang yang ditanam.

Tabel 4. Rerata LPT (g/m $\mathrm{m}^{2}$ hri $\left.^{-1} \tan ^{-1}\right)$ Sebagai Dampak Aplikasi Mulsa dan Generasi Umbi Bibit G2, G3,Lokal) Umur 30-105 hst

\begin{tabular}{|c|c|c|c|c|c|}
\hline \multirow{2}{*}{$\begin{array}{c}\text { Umur } \\
\text { Tanaman }\end{array}$} & \multirow{2}{*}{$\begin{array}{c}\text { Generasi } \\
\text { Umbi Bibit }\end{array}$} & \multicolumn{4}{|c|}{ Macam Mulsa } \\
\hline & & $\mathrm{tm}$ & mphp & $\mathrm{mpb}$ & $\mathrm{mCo}$ \\
\hline \multirow{3}{*}{ 30-105 hst } & G2 & $2,91 \mathrm{a}$ & $7,52 \mathrm{bc}$ & $9,51 \mathrm{~cd}$ & $2,79 \mathrm{a}$ \\
\hline & G3 & $4,40 \mathrm{ab}$ & $8,68 \mathrm{~cd}$ & $11,33 \mathrm{~d}$ & $2,68 \mathrm{a}$ \\
\hline & Lokal & $2,86 \mathrm{a}$ & $11,20 \mathrm{~d}$ & $9,87 \mathrm{~cd}$ & $4,35 \mathrm{a}$ \\
\hline BNT5\% & & & 3,13 & & \\
\hline
\end{tabular}

Keterangan: Bilangan yang didampingi oleh huruf yang sama, berbeda tidak nyata berdasarkan uji BNT pada taraf 5\%. hst $=$ hari setelah tanam. $\mathrm{mphp}=$ mulsa plastik hitam perak, $\mathrm{mpb}=$ mulsa plastik biru, $\mathrm{mCo}=$ mulsa Chromolaena odorata 


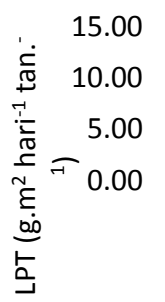

Macam Mulsa dan Generasi Umbi Bibit

Gambar 4. LPT pada Umur 30-105 hst

\section{Berat Segar Umbi Panen Total dan Klasifikasinya}

Hasil analisis ragam terhadap berat segar umbi panen total tanaman ${ }^{-1}$, petak $^{-1}$ dan hektar $^{-1}$ memperlihatkan pengaruh yang sangat nyata antar perlakuan kombinasi mulsa dan generasi umbi bibit.

Tabel 5 menunjukan bahwa, penggunaan mphp pada umbi bibit lokal memberikan berat segar umbi panen total tertinggi daripada perlakuan lainnya dan tidak berbeda dengan mpb pada umbi bibit G2, kemudian diikuti oleh penggunaan mphp pada umbi bibit G3, G2 dan penggunaan mpb pada umbi bibit lokal dan G3.

Umbi merupakan bagian ekonomis dari tanaman kentang yang dipanen. Gambar 5 menunjukan penggunaan mphp pada umbi bibit lo-kal mampu memberikan berat segar umbi panen total tertinggi, yakni 641,76 $\mathrm{g}$ tan. $^{-1}$ atau 32,09 petak $^{-1}$ atau 21,39 ton ha ${ }^{-1}$ dibandingkan perlakuan lainnya. Hal ini tidak lepas dari faktor per-tumbuhan yang cukup menunjang pertumbuhan dan pembesaran umbi seperti, luas daun, nilai ILD dan LPT. Selain itu, rbizosfer yang kondusif yang ditunjukan oleh suhu dan kelembaban tanah yang memadai sebagai dampak penggunaan mphp, memberikan kontribusi bagi peningkatan berat segar umbi. Nonnecke (1989) menyatakan, saat kritis bagi tanaman kentang adalah saat ketika dibutuhkan lebih banyak air, yaitu pada permulaan pembentukan umbi dan pembentukan stolon. Oleh karena itu untuk mencapai hasil yang tinggi, pada saat itu kadar air tanah pada kedalaman $15 \mathrm{~cm}$ dari permukaan ta-nah tidak boleh kurang dari $56 \%$.

Penggunaan umbi bibit lokal yang berukuran lebih besar dibanding G2 dan G3 turut berpe-ngaruh terhadap tingginya berat segar umbi pa-nen total. Ukuran umbi bibit lokal yang lebih be-sar memberikan cadangan makanan yang cukup, sehingga berpengaruh pada hasil umbi yang di-panen. Menurut penelitian Sutapradja (2008), walaupun jarak tanam yang digunakan untuk per-tanaman kentang sama, tetapi produksi umbi yang dihasilkan dapat berlainan karena bobot umbi yang digunakan untuk bibit berbeda. Sitompul dan Guritno (1995) berpendapat, salah satu faktor yang menentukan kualitas bahan ta-nam adalah banyaknya cadangan makanan yang terdapat pada bahan tanam tersebut.

Hasil analisis ragam terhadap rerata proporsi kelas umbi sedang dan sangat besar menunjukan pengaruh nyata antar perlakuan kombinasi mulsa dan generasi umbi bibit. Tabel 6 memperlihatkan, untuk umbi kelas sedang, tampaknya perlakuan tanpa mulsa pada umbi bibit G2 memberikan proporsi umbi sedang tertinggi 
dibandingkan perlakuan lainnya dan diikuti penggunaan $\mathrm{mCo}$ pada umbi bibit G2 dan G3.

Selanjutnya, pada kelas umbi sangat besar, penggunaan mphp pada umbi bibit lokal mem-berikan proporsi umbi sangat besar tertinggi di-banding perlakuan lainnya, namun tidak berbeda dengan penggunaan mphp pada umbi bibit G3 dan mpb pada umbi bibit G2, kemudian diikuti penggunaan mpb pada umbi bibit lokal, G3 dan mphp pada umbi bibit G2. Gambar 6 menunjukan penggunaan mphp pada umbi bibit lokal memberikan proporsi umbi kelas sangat besar yang cenderung lebih tinggi dibandingkan dengan perlakuan lainnya. Tingginya proporsi umbi pada kelas sangat besar, tidak lepas dari pertumbuhan tanaman yang baik seperti ditunjukan dengan luas daun, nilai ILD dan LPT yang baik. Kondisi ini memperlihatkan bahwa translokasi fotosintat berlangsung optimal akibat penyerapan sinar matahari yang optimum oleh tajuk tanaman ditunjang oleh permukaan mphp yang berwarna perak. Disamping itu didukung oleh suhu tanah pagi hari yang cukup rendah ya-itu $13^{\circ} \mathrm{C}$ bila dibandingkan dengan perlakuan lainnya. Menurut Timlin et al. (2006) suhu tanah yang rendah dapat mengurangi laju respirasi akar sehingga assimilat yang dapat disumbangkan untuk penimbunan cadangan bahan makanan menjadi lebih banyak dibanding pada perlakuan tan-pa mulsa.

Pada suhu tanah $30^{\circ} \mathrm{C}$ aktifitas beberapa enzim yang berperan dalam metabolisme pati ter-tekan, sehingga terjadi penurunan kadar pati pa-da umbi (Krauss dan Marschsur, 1984). Lebihlanjut Samadi (2007), menyatakan proses pem-bentukan umbi sangat dipengaruhi oleh suhu tanah yang rendah pada malam hari yang akan me-rangsang timbulnya hormon pembentuk umbi pada tanaman. Hormon ini akan diteruskan ke ujung stolon atau bakal umbi. Hasil penelitian Zhao at al. (2012) melaporkan penggunaan mulsa plastik selama awal pertumbuhan hingga panen meningkatkan tinggi tanaman, ILD, bobot kering tanaman, hasil umbi kentang dan WUE (Water use Efficiency.

Tabel 5. Rerata Berat Segar Umbi Panen Total (g tan. ${ }^{-1}$, kg petak ${ }^{-1}$, $\left.\mathrm{t} \mathrm{ha}^{-1}\right)$ Sebagai Dampak Aplikasi Mulsa dan Generasi Umbi Bibit (G2, G3, Lokal)

\begin{tabular}{|c|c|c|c|c|c|}
\hline \multirow{2}{*}{$\begin{array}{c}\text { Satuan } \\
\text { Berat }\end{array}$} & \multirow{2}{*}{$\begin{array}{c}\text { Generasi } \\
\text { Umbi Bibit }\end{array}$} & \multicolumn{4}{|c|}{ Macam Mulsa } \\
\hline & & $\mathrm{tm}$ & mphp & $\mathrm{mpb}$ & $\mathrm{m} C_{0}$ \\
\hline \multirow{4}{*}{$\begin{array}{c}g \\
\tan ^{-1}\end{array}$} & G2 & $124,23 \mathrm{a}$ & 378,06 abcd & 529,21 & $180,67 \mathrm{a}$ \\
\hline & G3 & 208,58 a & $490,46 \mathrm{~cd}$ & 385,69 abcd & 181,19 a \\
\hline & Lokal & $214,18 \mathrm{ab}$ & 641,76 & 484,45 bcd & $227,74 \mathrm{abc}$ \\
\hline & \multicolumn{2}{|c|}{ BNT5\% } & \multicolumn{2}{|c|}{271,61} & \\
\hline \multirow{4}{*}{ kg petak ${ }^{-1}$} & G2 & $6,21 \mathrm{a}$ & $18,90 \mathrm{abc}$ & 26,46 & 9,03 a \\
\hline & G3 & $10,43 \mathrm{a}$ & $24,52 \mathrm{bc}$ & $19,28 \mathrm{abc}$ & 9,06 a \\
\hline & Lokal & $10,71 \mathrm{ab}$ & $32,09 \quad \mathrm{c}$ & 24,22 bc & $11,39 \mathrm{ab}$ \\
\hline & \multicolumn{2}{|c|}{ BNT5\% } & \multicolumn{2}{|c|}{13,58} & \\
\hline \multirow{3}{*}{$\mathrm{t} \mathrm{ha}^{-1}$} & G2 & 4,14 a & $12,60 \mathrm{abcd}$ & $17,64 \quad d$ & $6,02 \mathrm{a}$ \\
\hline & G3 & 6,95 a & $16,35 \mathrm{~cd}$ & $12,86 \mathrm{abcd}$ & 6,04 a \\
\hline & Lokal & $7,14 \mathrm{ab}$ & 21,39 & $16,15 \mathrm{bcd}$ & 7,59 abc \\
\hline
\end{tabular}

Keterangan: Bilangan yang didampingi oleh huruf yang sama pada satuan berat segar yan sama, berbeda tidak nyata berdasarkan uji BNT pada taraf 5\%. mphp $=$ mulsa plastik hitam perak, mpb $=$ mulsa plastic biru, $\mathrm{mCo}=$ mulsa Chromolaena odorata. Ukuran petak $=15 \mathrm{~m}^{2}$ 


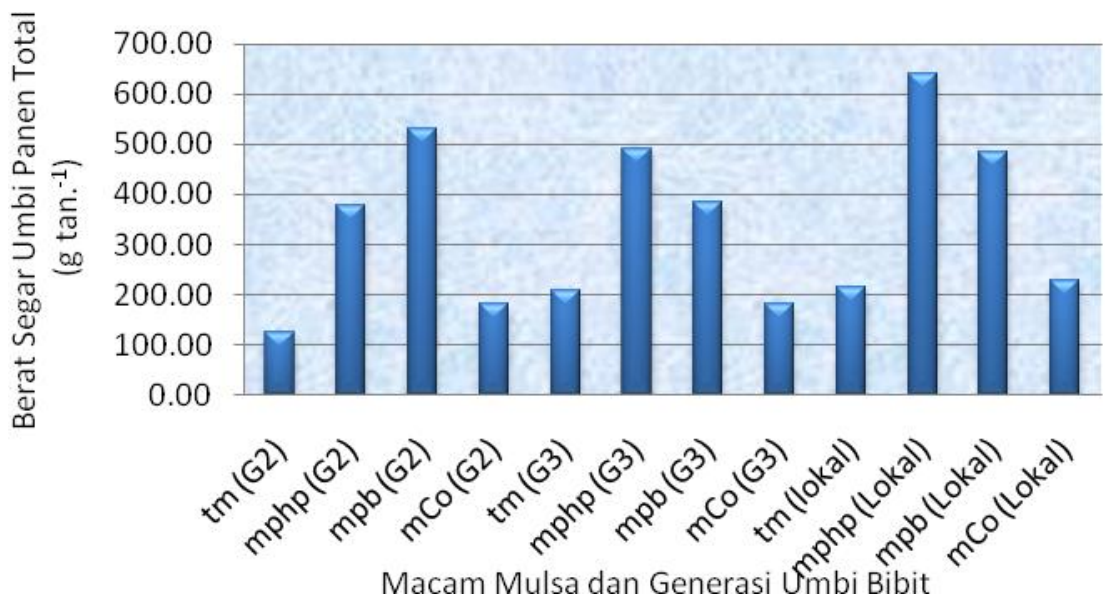

Gambar 5. Berat Segar Umbi Panen Total

Tabel 6. Rerata Proporsi Ukuran Umbi (\%) Kelas Sedang (51-100 g) dan Sangat Besar (>301 g)Berdasarkan Berat Segar Umbi

Sebagai Dampak Aplikasi Mulsa dan Generasi Umbi Bibit(G2, G3, Lokal)

\begin{tabular}{|c|c|c|c|c|c|}
\hline \multirow{2}{*}{ Kelas Umbi } & \multirow{2}{*}{$\begin{array}{c}\text { Generasi } \\
\text { Umbi Bibit }\end{array}$} & \multicolumn{4}{|c|}{ Macam Mulsa } \\
\hline & & $\mathrm{tm}$ & mphp & $\mathrm{mpb}$ & $\mathrm{mCo}$ \\
\hline \multirow{4}{*}{$\begin{array}{l}\text { Sedang } \\
(51-100 \mathrm{~g})\end{array}$} & G2 & $53,67 \quad \mathrm{c}$ & $28,24 \mathrm{ab}$ & 23,87 a & $41,23 \mathrm{bc}$ \\
\hline & G3 & $34,78 \mathrm{ab}$ & $25,38 \mathrm{ab}$ & $28,08 \quad a b$ & $41,01 \mathrm{bc}$ \\
\hline & Lokal & $34,21 \mathrm{ab}$ & $20,40 \mathrm{a}$ & $25,07 \mathrm{ab}$ & $33,36 \mathrm{ab}$ \\
\hline & & $\mathrm{T} 5 \%$ & 16,0 & & \\
\hline \multirow{3}{*}{$\begin{array}{l}\text { Sangat Besar } \\
\quad(>301 \mathrm{~g})\end{array}$} & G2 & $0,28 \mathrm{a}$ & $17,99 \mathrm{ab}$ & $35,38 \mathrm{~b}$ & $0,23 \mathrm{a}$ \\
\hline & G3 & $0,20 \mathrm{a}$ & $33,41 \quad b$ & $17,26 \mathrm{ab}$ & $0,23 \mathrm{a}$ \\
\hline & Lokal & $0,20 \mathrm{a}$ & $48,96 \mathrm{~b}$ & $31,55 \mathrm{ab}$ & 0,19 a \\
\hline
\end{tabular}

Keterangan: Bilangan yang didampingi oleh huruf yang sama pada kelas umbi yang sama berbeda tidak nyata berdasarkan uji BNT pada taraf 5\%. mphp $=$ mulsa plastik hitam perak, $\mathrm{mpb}=$ mulsa plastik biru, $\mathrm{mCo}=$ mulsa Chromolaen odorata .

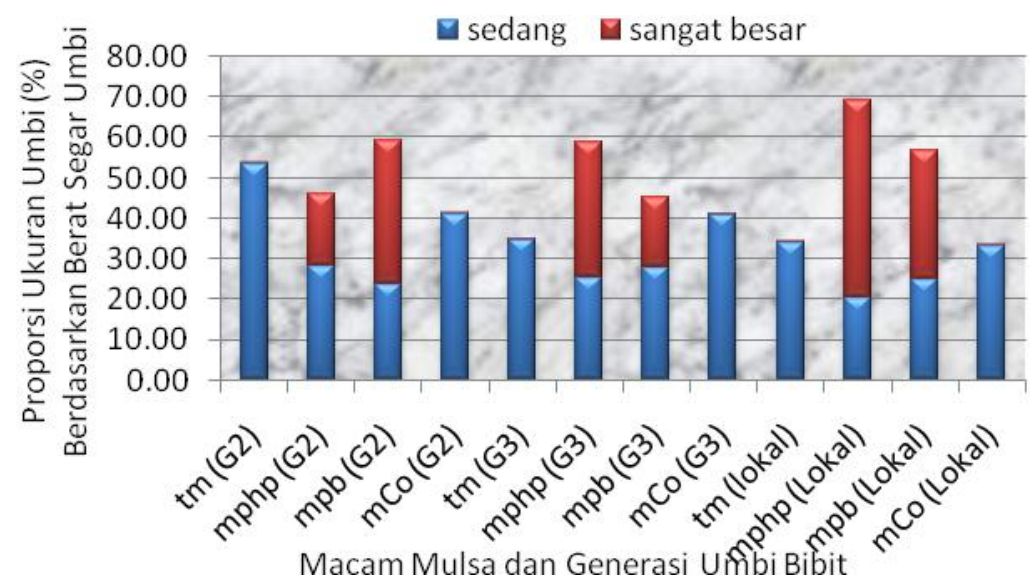

Gambar 6. Proporsi Ukuran Umbi Berdasarkan Berat Segar Umbi Panen 


\section{KESIMPULAN}

1. Aplikasi mphp pada umbi bibit lokal memberikan luas daun, nilai ILD dan LPT lebih tinggi dibandingkan perlakuan lainnya, dan mampu memberikan berat segar umbi panen total tertinggi yakni $641,76 \mathrm{~g}$ tanaman ${ }^{1}$ atau $32,09 \mathrm{~kg}$ petak $^{-1}$ atau $21,39 \mathrm{t} \mathrm{ha}^{-}$ 1 , tetapi hasil umbi tidak berbeda secara signifikan dengan pengguna-an mpb pada umbi bibit G2.

2. Aplikasi mphp pada umbi bibit lokal memberikan proporsi jumlah dan berat segar umbi kelas besar dan sangat besar lebih tinggi dibandingkan perlakuan lainnya.

3. Pertumbuhan dan hasil umbi optimum diperoleh pada kondisi suhu pagi dan siang masing-masing $13^{\circ} \mathrm{C}$ dan $20,33^{\circ} \mathrm{C}$ dan kelembaban pagi dan siang masing-masing $80,56 \%$ dan $47,50 \%$

4. Perlu penelitian lebih lanjut mengenai peman-faatan Cbromolaena odorata sebagai mulsa da-lam hal takaran, ketebalan, dan kondisi mulsa (aplikasi segar atau kering) mengingat karakternya yang cepat melapuk.

\section{UCAPAN TERIMA KASIH}

Terima kasih kepada bapak Inggi, kepala desa Ranupani dan Nur Hida Ismail, teman seperjuangan dalam penelitian.

\section{DAFTAR PUSTAKA}

Badan Pusat Statistik. 2013. Luas Panen, Produk-si, dan Produktivitas Kentang2009-2013.http:-

//www.bps.go.id

Badan Pusat Statistik. 2014. Produksi Tanaman Sayuran (Kentang) 20102014 http://www.bps.go.id

Basuki, N, A. Suryanto, M.D. Maghfoer, Koesri harti, N. Aini dan Rosilawati.1993. Upaya Pe- ningkatan Produksi Tanaman Kentang (Sola-num tuberosum L.) Berwawasan Lingkungan. Lap. Penelitian PSLH. UNIBRAW. Malang. $50 \mathrm{~h}$.

Bing Tang, J, N. Jenkins, C.E Watson, C.C Mc.Carty and R.G Creesch. 1996. Evaluation of Genetic Variances, Heritabilitas and Correlation for Yield and Fiber Traits Among Co-tton $\mathrm{F}_{2}$ Hy-brid Population. Euphytica. 91:315-322

El-Zohiri S.S.M. and M. M. Samy. 2013. Influ-ence of colored plastic mulches on a:-germination, growth and marketable yield of po-tato. J. Product. \& Dev., Potato and Vegetatively Propagated Vegetables Dep., Hort. Res., Inst., A.R.C., Egypt. 18(3):405.

Krauss, A and H. Marschner. 1984. Growth rate and carbohydrate metabolism of potato tu-bers explored to high temperature. Potash. Res. 27:297-303.

LuisI.J., L.S Ricardo and A. V. A. Luishttp://www.researchgate.net/p ublication/232840439Colored plasti c mulches affect soil temperature and tuberproduction of potato [accessed Apr 13, 2015].

Mahmood, M., K. Farroq, A. Hussain, R. Sher. 2002. Effect of mulching on growth and yield of potato crop. Asian J. of Plant Sci. 1(2):122-133.

Midmore, D. J. 1984. Potato (Solanum tubero-sum. L) in The Hot Tropics. I. Soil Temperature Efects on Emergence, Plant Development and Yield. Field Crop. Res. 8: 25-27.

Odjugo P. A. O. 2007. The effect of tillage sys-tem and mulching on soil microclimate, growth and yield of white yam (Dioscorea rotundata) in Midwestern Nigereia. J. of food, Agric. \& Environ 5 (2):164-169. 
Rukmana, R. 2002. Usaha Tani Kentang Sistem Mulsa Plastik. Kanisius. Yogyakarta. 44 hal.

Samadi B. 2007. Kentang dan Analisis Usaha tani Kentang. Kanisius. Yogyakarta. hal. 50-60

Sunaryono, H. 2007. Petunjuk Praktis Budidaya Kentang. AgroMedia Pustaka, Jakarta. hal. 44

Timlin, D., S.M.L. Rahman, J. Baker, V.R Reddy, D. Feisher, and B. Quebedeaux. 2006. Whole plant photosynthesis, development, and car-bon partitioning in potato as a function of temperature. Agron. J. 98(5):1195-1203.

Tinambunan E, Setyobudi L, Suryanto A. 2014. Penggunaan Beberapa Jenis Mulsa terhadap Produksi Baby Wortel (Daucus carota L.) Varie-tas Hibrida. J. Produksi Tanaman, 2 (1) 24:25-30
Wang, X. Q., S. X. Li and Y. J. Gao. (1998), Effect of plastic film mulching on ecophysiology and yield of spring maize on arid lands. Acta Agro-nomica Sinica, 24, 348353.

Wattimena, G.A. 2000. Pengembangan Pro-pagul Kentang Bermutu dan Kultivar Kentang Unggul dalam Mendukung Peningkatan Pro-duksi Kentang di Indonesia. Orasi Ilmiah Guru Besar Tetap Ilmu Hortikultura, Fakultas Per-tanian IPB, 2 September 2000. IPB Bogor.

Zhao H., Y. C.Xiong., F Min Li ., R. Y Wang., S.C Qiang.,T. F Yao., and F Mo. 2012. Plastic film mulch for half growing-season maximized WUE and yield of potato via moisture temperature improvement in a semi-arid agroecosystem. J. Agricultural Water Mana-gement 104: 68-78. 